\title{
O ensino superior privado: o conflito entre lucro, expansão e qualidade
}

Gustavo Javier Castro Silva

Curso: Doutorado em Sociologia

Data da defesa: 17 de março de 2008

Orientador: Prof. Dr. Lúcio de Brito Castelo Branco

\section{Resumo}

A presente pesquisa procura identificar e compreender quais os elementos que obstaculizam ou impulsionam a construção de uma universidade privada no Brasil. O problema central do trabalho consiste em verificar a possibilidade de construção de uma universidade privada sob pressão das forças do mercado e do imperativo de um negócio voltado para o lucro, mesmo quando há a presença de um estrato acadêmico qualificado e, sobretudo, a presença decisiva do papel regulador do Estado. A análise e a compreensão desse processo concernem a fenômenos imanentes de um contexto patrimonialista e de tradição cultural ornamental.

A hipótese de trabalho considera que a construção de uma universidade privada depende não somente das forças do mercado, do Estado e da eventual existência de um estrato acadêmico capacitado e motivado, mas, sobretudo, da política como instrumento facilitador de qualquer empreendimento privado. Parte-se de uma análise sociológica da situação do ensino superior no Brasil e no Distrito Federal mediante a descrição crítica dos processos de credenciamento da Faculdade Euro-Americana e do Centro Universitário EuroAmericano. A seguir, caracterizam-se as dificuldades fundamentais 
da institucionalização de um empreendimento privado de ensino superior, bem como os limites e o papel regulador do Estado no ensino superior brasileiro em função da cristalização histórica de um processo de privatização do Estado pelas classes dominantes.

As Instituições Privadas de Ensino Superior, em virtude de seu caráter complementar e acessório do "sistema" público e, acima de tudo, pela sua origem, via de regra, patrimonialista e pela sua total subordinação aos imperativos inerentes a um mercado agonicamente competitivo e dependente de financiamentos e benesses do Estado, têm remota probabilidade de se tornarem universidades.

Palavras-chave: ensino superior, ensino privado, universidade privada. 